\title{
Legitimizing Workforce Reduction: A Review on Impact of COVID-19 Outbreak to the Economy
}

\author{
Norman Zakiyy \\ Faculty of Shariah and Law, Universiti Sains \\ Islam of Malaysia, Putra Nilai, Negeri Sembilan, Malaysia
}

\section{Abstract}

COVID-19 outbreak continues to impact business organizations around the world financially. One major concern is the common practice of business organizations to reduce their workforce. Issues might arise from such management decisions. The purpose of this conceptual paper is to analyze the legitimacy of managerial decisions relating to workforce reduction. The methodology of legal analysis was used by referring to and reviewing literature in Malaysia, Singapore and the United Kingdom. Major findings show that management decisions on workforce reduction especially during the COVID-19 outbreak must accord with employment law and existing government measures. Apart from that, an employer's failure to resolve issues of workforce reduction according to the law and government measures would result in trade disputes and eventual court action. The findings of this study can assist employers to make sound management decisions with valid reasons in situations, not within their control.

Keywords: legitimacy, workforce reduction, management, COVID-19

\section{Introduction}

The Covid-19 pandemic was declared by the World Health Organization (WHO) as a global issue. The World Bank highlights "the need for urgent action to cushion the pandemic's health and economic consequences, protect vulnerable populations, and set the stage for a lasting recovery" (The World Bank, 2020). Thus, it demands serious consideration especially when it has caused many business organizations to close down businesses. The International Labour Organization reported that on 7 April 2020 , the world had experienced an estimated of $6.7 \%$ loss of job hours in the second quarter of 2020, an equivalent to 195 million full-time jobs (Financial Times, 2020). Job losses have been reported worldwide and has affected the source of income and economic activities (Astuti, \& Mahardhika, 2020). There is also a fear of possible recession in the near future (Carlsson-Szlezak, Reeves, and Swartz, 2020). In China, 5 million people lost their jobs in January and February 2020 (Cheng, E. 2020). In 
Canada, 44 per cent of Canadian households had lost work due to the COVID-19 outbreak (Abedi, 2020). .

Workforce reduction is one measure taken by many business organizations around the globe during the Covid-19 outbreak. Despite various government financial measures, there is a fear that disguised retrenchments will be used by employers as a drastic cost-cutting measures to survive the throughout the outbreak (Kaur, witherworldwide, 2020). The effects of workforce reductions are known such as loss of jobs and economic loss. The underlying belief is that workforce reduction is harmful to mental health and the economy. Workforce reduction, which is done not in accordance with the law would result in employers having to bear costly and unending legal suits. Thus, employers need to find reasons backed by the law for justifying the reduction of their companies' workforce.

The significance of this study is to provide guidance to employers and employees on workforce reduction by reviewing the appropriate laws and government measures on maintaining the workforce especially during the COVID-19 outbreak. A comparison between various laws and government policies in different countries used to address the problems that arise out of the COVID-19 outbreak might be useful in the sense of adopting and improving the current applicable laws or policies of a country. Both the legal systems of Malaysia and Singapore are based on the English Common Law System. The laws applicable in Malaysia, Singapore, and the United Kingdom are considered as persuasive in the courts of these countries, and thus they were analyzed in this study.

The purpose of this study is to analyse the legitimacy of managerial decisions relating to workforce reduction. Thus, this study aims firstly, to identify the relationship between management decision and the laws and government measures on workforce reduction that are made during the COVID-19 outbreak; and secondly, what are the consequences of not adhering to the laws and government measures in a workforce reduction. Thus, it is important to answer the following questions, namely (i) What is the relationship between management decision on workforce reduction and the laws and government measures made during the COVID-19 outbreak; and (ii) What are the consequences of not adhering to the laws and government measures in a workforce reduction. Knowing how to address issues on workforce reduction and knowing what practical mistakes to avoid will assist greatly to employers on how businesses have implemented retrenchments (both properly and improperly from the legal perspective). Thus, this study addresses the situations in Malaysia, Singapore and the United Kingdom and set out very brief summaries of a selection of statutory laws, reported case laws and government measures on the subject of workforce reduction with emphasis on the COVID-19 outbreak. 


\section{Literature Analysis}

\subsection{Government Measures/Laws to prevent outbreaks and cushion the financial impact of COVID-19}

\section{Malaysia}

Malaysia's first phase of prevention of movement control in response to COVID-19 outbreak began with the Movement Control Order (MCO) on 16 March 2020. The MCO was made under the Prevention and Control of Infectious Diseases Act 1988 (Act 342) ("Regulations") and the Police Act 1967. Restrictions under the MCO included prohibition of travelling abroad, mass movements and gathering and closure of private premises except those in essential services. Further to the MCO, specific regulations were introduced, namely the Prevention and Control of Infectious Diseases (Measures within the Infected Local Areas) Regulations 2020 ("Regulations") concerning the movement restriction for the period 18 March 2020 to 31 March 2020; and the Prevention, and Control of Infectious Diseases (Measures within Infected Local Areas) (No.2) Regulations 2020 (in force from 1 April 2020 to 14 April 2020).

The Temporary Measures for Reducing the Impact of Coronavirus Disease 2019 (Covid-19) Act 2020 operates for 2 years effective from 23 October 2020 provides relief to a party who is unable to perform his contractual obligation by prohibiting the other party to the contract to exercise his right under the contract (section 7 of the Act). Section 9 of the Act promotes mediation as a mechanism to resolve issues on a contractual obligation. The Malaysian Government had also issued the first stimulus package (valued at US $\$ 4.8$ billion) to counter the impact of the most vulnerable sectors and households. Subsequently the second package (valued at US\$57 billion), focused on enhancing the existing financing facilities issued in the first stimulus package apart from supporting small and medium-sized enterprises (SMEs), assist low and middle-income households, and provide fiscal injections to strengthen the national economy (Asian Briefing, 2020).

\section{Singapore}

The COVID-19 (Temporary Measures) Act 2020 (No. 14 of 2020) sets out temporary measures for businesses and individuals impacted by the measures taken to reduce the spread of COVID-19. It also provides restrictions on the time, manner or extent for the carrying out of any business (see Part VII Article 34). In relations to reducing the impact of COVID-19 outbreak on the economy, the Act, among others suspends contractual obligations in contracts, provides financial relief to individuals, businesses and firms; and restricts certain activities by the general public to prevent the spread of COVID-19 (see Part 2, Temporary Relief for Inability to Perform Contracts and Part 3, Temporary Relief for Financially Distressed Individuals, Firms and Other Businesses). 


\section{The United Kingdom}

The Coronavirus Act 2020 (2020 c.7) (CA 2020) came into effect on 25 March 2020 and among others allows the government to among others restrict or prohibit public gatherings (section 52), order businesses such as shops and restaurants to close and temporarily detain people suspected of COVID-19 infection (section 51). The CA 2020 also provides for measures to combat the economic effects of the outbreak such as protect emergency volunteers from becoming unemployed (section 9). The government also will reimburse the cost of statutory sick pay for employees affected by COVID-19 to employers.

\subsection{Employment Law \& Government Measures concerning Workforce Reduction during COVID-19 Outbreak}

\subsubsection{Malaysia}

Redundancy Law: Reducing workers by reason of redundancy in the workforce is recognized as a management prerogative in Malaysia. The employer has the right to reduce the workforce due to the reason that fewer employees of whatever kind are required and not whether a particular work is no longer in existence (see Stephen Bong v FOB (M) Sdn. Bhd. \& Anor (1999) 3 MLJ 411; and Pipraich Sugar Mills v Pipraich Sugar Mills Mazdoor Union AIR 1957 SC 95 ). The court will not interfere with such decision as long as it is based on reasonable grounds, done in good faith and without exploitation (see Radio \& General Trading Sdn Bhd and Pui Cheng Teck \& Anor (Award 243/1990)).

Redundancy must be actual redundancy. In Tang Chooi Kim lwn. Wasco Management Services Sdn Bhd/Wasco Coatings Limited [2018] 2 LNS 0175, the Industrial Court held that the employer failed to show redundancy on a balance of probability as the job and responsibility of the claimant (employee) was still in existence. Similarly, in the Court of Appeal case of Bayer (M) Sdn. Bhd. v. Ng Hong Pau [1999] 4 AMR 3913, His Lordship Justice Shaik Daud Md Ismail (as he then was) held that the burden is on (the employer) to prove actual redundancy on which the dismissal was grounded and that is where the workload was taken over by other colleagues.

The word 'retrenchment' has been defined as the discharge of surplus labour or staff by an employer for any reason whatsoever otherwise than as a punishment inflicted by way of disciplinary action." (Aminuddin, 2006) The principle derived from Malaysian industrial court awards shows that retrenchment exercise must be done in good faith (bona fide). In Mohd Zakir Yusoff v. Telarix (M) Sdn Bhd (Award No. 349 of 2020), the court found that the employers had failed to prove real and bona fide redundancy and decided that the dismissal of the employee was without just cause or excuse (see also William Jacks \& Co. (M) Sdn. Bhd. v S. Balasingam (1987) CLJ 1; and East Asia Company (M) Bhd. v Valen Noel Yap (Award No. 130 of 1987)). 
According to Aminuddin (2006), an employer is required to follow the golden principle, namely "Last in First Out" (LIFO) as a guide in the retrenchment exercise. In Tharmabalan Suppiah Velliah v. MSL Travel Sdn Bhd (Award No. 3081 of 2019), the Industrial Court upheld the employer's reorganization plan and had observed that the employer had complied with the LIFO principle). An employer must ensure that the retrenchment of a selected employee in the workforce under the LIFO principle is based on the reference of the same category of employment or employees doing similar work (see Malayan Tiles Manufacturers Ltd. v Non-Metallic Mineral Products manufacturing Employees Union (Award No. 11 of 1986); and Aluminium Company of Malaysia v Jaspal Singh (1989) 2 ILR 558).

A number of industrial court awards have shown that an employer must have valid reasons for not following the LIFO principle (see Ganda Palm Services Sdn. Bhd., Teluk Intan v Ng Wah Chiew and 2 others (Award 40/1986 ILR), CH Reinforcing Steel (M) Sdn Bhd v Abu Samah Abbas (2001) 1 ILR 903; and National Union of Cinema \& Amusement Workers v Shaw Computer \& Management Services Sdn. Bhd (Award No. 27 of 1978)). Apart from existing laws, the Code of Conduct for Industrial Harmony 1975 ('CCIH') assist employers to (avoid retrenchment by limiting the number of working hours; stop recruitment; avoidance of overtime work; to restrain work for the rest day; to trim down on salary; and/or to suggest temporary lay-offs.

Retrenchment Benefits: According to Regulation 6 of the Employment (Termination and Lay-Off Benefits) Regulations 1980, employees whose monthly salary is RM2000 and below and dismissed for redundancy reason are eligible for retrenchment benefits. An employee who is not governed by the Employment Act 1955 may have his retrenchment benefit, provided for either in a collective agreement or contract of employment. An employee who is governed neither by the collective agreement or individual contract of employment is not protected under the Employment Act 1955 and his entitlement to retrenchment benefits is wholly dependable upon the discretion of his employer.

Unlawful Dismissal: Reducing the workforce must be done without the ulterior intention to keep away an employee out of an organization. Thus, dismissal of an employee must be done on the basis of "just cause and excuse". It is settled law that the Industrial Court in hearing a dispute under section 20 (1) of the Industrial Relations Act 1967 (IRA 1967) will decide whether the dismissal of a workman by reason of misconduct has been established prior to deciding whether the proven misconduct itself is a just cause and excuse for dismissal (see the Federal Court decision of Milan Auto Sdn. Bhd. v Wong She Yen (1995) 3 MLJ 537 and Goon Kwee Phoy v J \& P Coats (M) Bhd, [1981]2 MLJ 129).

Doctrine of Frustration in Contract: An employment contract is frustrated in a way where it can be ended without been terminated by the employer or his employee and is caused by situations beyond the control of both parties to the contract (Aminuddin, 2006). Frustration of contract arises not only due to certain unforeseen circumstance 
not within control, but also in a situation where neither party caused nor contemplate the supervening event (Lee \& Detta, 2017). Section 57 (2) of the Contracts Act 1950 states that a contract is frustrated when there is a change in the circumstances which renders a contract legally or physically impossible of performance. For instance, in the case of H.A. Berney v Tronoh Mines Ltd. [1949] 15 MLJ 4, the court held that the invasion of Malaya by the Japanese frustrated the performance of the contract and thus there was no breach of contract by the employer. However, the doctrine of frustration does not apply when there is fault in the party pleading it (see Yee Seng Plantations Sdn. Bhd. V Kerajaan negeri Terengganu \& Ors. [2000] 3 CLJ 666); where the particular state of affairs ceases to exist (Codelfa Construction Pty Ltd. v State rail Authority (NSW) [1982] 149 CLR 337); where the contract is still possible of performance (see Eastacres Development Sdn Bhd v Fatimah Mutallip \& Anor [2000] 5 CLJ 379) and in a self-induced frustration (Dato' Yap Peng \& Ors v Public Bank Bhd \& Ors [1997] 3 MLJ 484.

Government Measures: In 24 March 2020, the Ministry of Human Resources ("MHR") released its Frequently Asked Questions (FAQ) on Movement Control Order, Ministry of Human Resources the COVID-19 outbreak ("FAQ"). Section 5 of the FAQ mentions that employers should comply with 3 basic requirements: (i) There must be a genuine financial impact on the business; (ii) measures have been taken and exhausted other means before opting for retrenchment; and (iii) Foreign workers are selected for retrenchment first if retrenchment is unavoidable. The LIFO principle must be adhered to if retrenchment involves local workers. However, in cases where employers believe that they are backed by strong justifications for exercising retrenchment, LIFO may be disregarded (FAQ Vol. 3, Ministry of Human Resources of Malaysia, 2020).

In addition, the MHR has encouraged employers to adhere to the "Guidelines on Handling Issues Relating to Contagious Outbreaks Including Novel Coronavirus (2019-NCOV)" (Ministry of Human Resources Guidelines, Press Statement dated 5 February 2020). Paragraph (iii) of the guidelines briefly seeks employers to ensure that employees be provided with full pay upon receiving quarantine orders from a registered medical practitioner, upon return from an official duty from countries with COVID-19 cases. Paragraph (iv) of the guidelines seeks employers to not to prevent any employees from attending work if no quarantine orders are issued against them (MInistry of Human Resources Guidelines, 2020).

\subsubsection{Singapore}

Redundancy Law: The words 'redundancy' or 'retrenchment' are not defined in Singapore's Employment Act (Cap 91). Section 45 of the Act provides that no employee who has been in continuous service with an employer for less than three years shall be entitled to any retrenchment benefit on the termination of his service by the employer on the ground of redundancy or by reason of any re-organization of the employers' profession, business, trade or work. However, the Court of Appeal in 
Bethlehem Singapore Pte Ltd v Ler Hock Seng \& Ors [1995] 1 SLR 1 held that the particular section cannot be construed to imply that employers are required to pay retrenchment benefits to their employees with more than three years' continuous service with them.

Retrenchment Benefits: Retrenchment benefits in Singapore depends on the size and financial position of the company and is normally stated in the contract of employment to avoid any conflict.

Unfair Dismissal: Section 14(2) of the Employment Act states that an employee may lodge a claim for wrongful dismissal if the employee feels that he/she was dismissed without just cause or excuse.

Doctrine of Frustration in Contract: In Singapore, employers are not encouraged to rely on the doctrine of frustration during the trying period of the MCOs. The legitimate reason is that the doctrine is only applicable in situations where contractual parties are finding it impossible to perform the contract rather than facing difficulty to perform the contract.

Government Measures: The Ministry of Manpower ("MoM") guidance on workforce reduction is to: (i) decide on manpower needs in the long run; (ii) inform MOM before carrying out any retrenchment exercise; (iii) consult with the union for a unionised company; (iv) be non-discriminatory against employees; (v) treat the workforce with dignity and respect; and (vi) lengthening the retrenchment notice period. During the retrenchment exercise, an employer should (i) Pay all salaries; and (ii) Help affected employees look for alternative jobs (Ministry of Manpower website, 2020). The MOM also requires employers to notify it in relations to matters on no-pay leave and costsaving measures. Prior to resorting to no-pay leave (as a last resort exercise), employers are to observe the Tripartite Advisory on Managing Excess Manpower and Responsible Retrenchment measures which include training, redeployment, flexible work schedule, shorter work week and temporary layoff. (Ministry of Manpower, 2020).

Section 2 of the Employment (Returns on Salary Reduction Measures) Notification 2020 which came into effect on 29 May 2020 allows an employer to cut operating expenses by reducing the working hours of an employee that results in a reduction of the his/her salary or by giving an employee a leave of absence with reduced salary or without salary for an agreed period; and a reduction in an employee's gross rate of pay, but not a reduction or withholding of a wage increment.

\subsubsection{The United Kingdom}

Redundancy: Redundancy exercise is as follows: (i) last in, first out; (ii) volunteer basis; (iii) disciplinary records; and (iv) staff appraisal markings, skills, qualifications and experience. However, an employer can make an employee redundant without having to follow a selection process if the employee's job has ceased to exist. 
Employers have to comply with additional statutory obligations if they are planning a large number of redundancies. According to Darbourne (2014), where at least 20 redundancies are planned within a period of 90 days' or less, the employer must consult collectively with appropriate employee representatives about the redundancies.

Retrenchment benefits: Section 135 of the Employment Rights Act 1996 provides that an employer shall pay his employee, who is made redundant, a sum of "statutory redundancy pay" if the latter has been working for the former for 2 years or more. His entitlement would be based on a statutory formula as follows: (i) half a week's pay for each full year if he were under 22; (ii) one week's pay for each full year if he were 22 or older, but under 41; and (iii) one and a half week's pay for each full year if he were 41 or older; and the length of service is capped at 20 years. In addition, the employee may be entitled to contractual redundancy payments and payment in lieu of notice if notice is not given (a sum equivalent to the salary which he would have received during the contractual notice period).

Unfair Dismissal: Section 140 of the Employment Rights Act 1996 states an employee is not entitled to redundancy payment if he has been dismissed by his employer by reason of the employee's conduct. However, a genuine redundancy in the absence of a fair procedure entitles a dismissed employee to file an action for unfair dismissal.

Government Measures: In March 2020, the UK Government announced the implementation of the Coronavirus Job Retention Scheme (CJRS). The purpose of CJRS is to provide for payments to be made to employers on a claim made in respect of them incurring costs of employment in respect of furloughed employees (see Paragraph 2.1 of CJRS). Under paragraph 6.1 of CJSR, an employee is a furloughed employee if (a) the employee has been instructed by the employer to cease all work in relation to their employment, (b) the period for which the employee has ceased (or will have ceased) all work for the employer is 21 calendar days or more, and (c) the instruction is given by reason of circumstances arising as a result of coronavirus or coronavirus disease. Under the first phase of the scheme, employers could reclaim up to $80 \%$ of furloughed staff wage costs from Her Majesty's Revenue and Customs (HMRC). A further flexible phase allows employees to be partially furloughed, combined with part-time working (Coronavirus (Covid-19): Redundancy Guide, 2020).

\section{Methodology}

Studies in law and society generally involve analysis of statutes, reported case laws, court procedural rules and court practice directions. This study depended largely on secondary data. The major sources of data include statutory laws, journal articles, reported cases, law books and relevant information retrieved from the internet were analysed and discussed. The methods employed in this study were descriptive aimed at fact finding and positive analytical criticisms. 


\section{Findings, Discussion and Analysis}

The findings show that management decisions on workforce reduction especially during the COVID-19 outbreak must accord with employment law and existing government measures. Apart from that, an employer's failure to resolve issues of workforce reduction, according to the law and government measures would result in trade disputes and eventual court action.

Employers who intend to reduce their workforce must not forget that they have been given numerous financial aids by the government to cushion the economic impact of COVID-19 outbreak on their businesses. These aids are in the form of stimulus packages or financial aids to employers such as the Coronavirus Job Retention Scheme (CJRS) United Kingdom in respect of furloughed employees (see Paragraph 2.1 of CJRS). Similarly, the Employment (Returns on Salary Reduction Measures) Notification 2020 introduced in Singapore has allowed employers to reduce operating expenses such as by reducing the working hours of an employee that results in a reduced amount of take-home salary.

Companies generally attempt to reduce their workforce as a result of a merger or takeover. Employers are only allowed to do so, subject to the governing laws of their respective countries. The continuing inability of employers to manage the financial performance of their businesses due to COVID-19 outbreak should be accepted as a legitimate reason to reduce their workforce. Based on the cited case laws and statutory laws in the literature review, it is found that employers are generally allowed to reduce their workforce if there is genuine redundancy. The literature review also shows that the countries under study require an employer to follow the golden principle, namely "Last in First Out" (LIFO) as a guide in the retrenchment exercise.

Noticeably, the implementation of movement control orders and government measures to curb the COVID-19 outbreak has a drastic effect on the daily routine of an employee and even an employer. In most countries, the new normal of life requires most employees to work from home (WFH). Restrictions under the movement control orders usually included prohibition of mass movements and closure of private premises in 'red zone areas' except those in essential services.

As observed, government measures generally require employers to pay their employees their salary as normally received if they are working from the office. The current situation made it difficult for employers to expect employees to fulfil their contractual obligations as efficiently as possible, especially when they are deprived from moving freely. This raises the issue of whether employers can treat the employment contract as frustrated and used this as a reason to reduce their workforce by way of retrenchment.

Based on the analysis of the literature, retrenchment should only be considered as a last resort after other methods prescribed by government measures to avoid 
retrenchment have not been effective. In addition, the principles prescribed under the Code of Conduct for Industrial Harmony 1975 ('CCIH') need to be observed to avoid retrenchment by limiting the number of working hours, stop recruitment, avoidance of overtime work, to restrain work for the rest day, to trim down on salary, and/or to suggest temporary lay-offs.

Employers are not supposed to rely on the doctrine of frustration as a result of the movement control order. Most employees are capable of discharging their obligations by WFH. A contract is not frustrated when it is still possible of performance (see Eastacres Development Sdn Bhd v Fatimah Mutallip \& Anor [2000] 5 CLJ 379). The rationale is acceptable from the lens of both contracting parties and is good from the aspect of improving harmony in industrial relations. In Malaysia, The Ministry of Human Resources (MHR)'s “Guidelines on Handling Issues Relating to Contagious Outbreaks Including Novel Coronavirus (2019-NCOV)" seek employers provide employees with full pay upon receiving quarantine orders upon return from an official duty from countries with COVID-19 cases. There is no reason for treating the contract as frustrated when employees are capable of rendering their services in exchange of remuneration.

Frustration of contract can arise due to certain unforeseen circumstance not within control and in a situation where neither party caused nor contemplate the supervening event (Lee \& Detta, 2017). The employer should be slow to terminate contracts on the basis of frustration. The Employers should not reduce their workforce when they refused to adhere to government measures to cushion the economy due to COVID-19 outbreak. Numerous government incentives (such as where employers could reclaim up to $80 \%$ of furloughed staff wage costs in the United Kingdom) are meant to cushion the financial problems faced by the employers. However, refusal to receive incentives might be considered as a self-induced frustration (see Dato' Yap Peng \& Ors v Public Bank Bhd \& Ors [1997] 3 MLJ 484). Likewise, the workforce should not be reduced merely due to the assumption that the COVID-19 outbreak would last for a number of years to come.

As previously mentioned in the literature review, the doctrine of frustration does not apply when there is a fault in the party pleading it (see Yee Seng Plantations Sdn. Bhd. v Kerajaan negeri Terengganu \& Ors. [2000] 3 CLJ 666) and where the particular state of affairs ceases to exist (Codelfa Construction Pty Ltd. V State rail Authority (NSW) [1982] 149 CLR 337). Frustration of contract might take place if it is directly related to situations whereby an employee has been detained by the authorities due to possession of illegal drugs, the death of an employer or employee, and the mental of physical incapacity of an employee which makes him or her impossible to fulfill his or her obligations under an employment contract.

Management decision is generally made by the management itself without interference from any other party. However, unilateral decisions can be disastrous if made in disregard of the governing law and government measures. This would result 
in trade disputes and eventual court action. In retrenchment exercise, for instance, an employer should ensure that all salaries, including unused annual leave are paid to the retrenched employees on their last day of work; apart from helping them to look for alternative jobs.

The industrial relations system is a tripartite system which involves the participation of the employer, the employees and the government. The literature shows that employers are safeguarded to a certain extent from legal suits by their employees when the government have some right to participate in the decision-making process of the employer. Thus, it is important for the parties to work together in order to ensure industrial harmony in the workforce, especially in facing the effects of COVID19 outbreak. Making unilateral decisions are risky for the employers and should be exercised diligently in order to avoid trade disputes in the forms of strikes, lockout and picketing. In relation to this, Malaysian employers can find guidance from the recent introduction of the Temporary Measures for Reducing the Impact of Coronavirus Disease 2019 (Covid-19) Act 2020 which provides relief to a party who is unable to perform his contractual obligation as a result of the measures under the Prevention and Control of Infectious Diseases Act, 1988. Under the said Act, employers and employees can also resort to mediation to resolve their disputes.

\section{Conclusion}

Retrenchment is seen as dismissals or may even be seen as unfair dismissals. Thus, employers must take precautionary steps to avoid the long term inconvenience of having to defend court actions filed against them by aggrieved employees. One way of avoiding such situation is to properly consider government measures and employment laws as well as other applicable laws regulating the workforce. The impact of COVID-19 on the economy would not diminish in a couple of years. With movement control orders, the predicaments faced by employers and employees would not subside.

It is only hoped that governments around the world would provide continuous support and also allow a large number of economic sectors and business activities to operate. As the new normal is the way of life, employers and employees need to adapt to the new working condition with strict compliance to the health standard operating procedures ("SOP"). Most importantly, employers must not violate the laws and adhere to government measures on workforce reduction in order to avoid unending legal actions taken against them by their employees who are aggrieved by their management decisions.

\section{References}

[1] Abedi, M. (2020)."44\% of Canadian households report lost work amid COVID-19 pandemic: poll". Global News, https://globalnews.ca/news/6726202/coronavirus-canada-job-loss-poll/ 
[2] Astuti, P.B., \& Arya Samudra Mahardhika, A.S. (2020). Jurnal Inovasi Ekonomi, Vol. 05 No. 02 June 2020 Page 85-92 http://ejournal.umm.ac.id/index.php/jiko)

[3] Aminuddin, M. (2006). Malaysian Industrial Relations and Employment Law. 5th Edition. McGraw-Hill Education, Malaysia.

[4] Asean Briefing. (2020). Malaysia Issues Second Stimulus Package to Combat COVID-19: Salient Features

https://www.google.com/search?q=malaysia+government+covid+19+supp ort\&oq=Malaysian+government+covid $+19+$ s\&aqs $=$ chrome. $1.69 \mathrm{i} 57 \mathrm{j} 0 \mathrm{i} 22 \mathrm{i} 30 \mathrm{i}$ 457.22865j0j7\&sourceid=chrome\&ie=UTF-8

[5] Aluminium Company of Malaysia v Jaspal Singh (1989) 2 ILR 558

[6] Bethlehem Singapore Pte Ltd v Ler Hock Seng \& Ors [1995] 1 SLR 1

[7] Bayer (M) Sdn. Bhd. v. Ng Hong Pau [1999] 4 AMR 3913

[8] Carlsson-Szlezak, P., Reeves, M and Paul Swartz, P. What Coronavirus Could Mean for the Global Economy, Harvard Business Review, March 3, 2020, 210.

[9] Coronavirus (Covid-19): Redundancy Guide, 2020). https://www.cipd.co.uk/knowledge/fundamentals/emplaw/redundancy/coronavirus-guide

[10] Coronavirus Act 2020 (United Kingdom)

[11] Coronavirus Job Retention Scheme (CJRS) (United Kingdom)

[12] Coronavirus (Covid-19): Redundancy Guide (United Kingdom). Employment (Returns on Salary Reduction Code of Conduct for Industrial Harmony 1975 (Malaysia)

[13] COVID-19 (Temporary Measures) Act 2020 (No. 14 of 2020) (Malaysia)

[14] Codelfa Construction Pty Ltd. v State rail Authority (NSW) [1982] 149 CLR 337

[15] CH Reinforcing Steel (M) Sdn Bhd v Abu Samah Abbas (2001) 1 ILR 903

[16] Chooi Kim v Wasco Management Services Sdn Bhd/Wasco Coatings Limited [2018] 2 LNS 0175

[17] Dato' Yap Peng \& Ors v Public Bank Bhd \& Ors [1997] 3 MLJ 484

[18] Eastacres Development Sdn Bhd v Fatimah Mutallip \& Anor [2000] 5 CLJ 379

[19] Darbourne, C. (UK) (June 12, 2014).What rights do employees have on redundancy in the

UK?https://www.globalworkplaceinsider.com/category/europe

[20] Evelyn Cheng, E, "Roughly 5 million people in China lost their jobs in the first 2 months of 2020". (published 16 March 2020).

https://www.cnbc.com/2020/03/16/china-economy-millions-lose-theirjobs-as-unemployment-spikes.html

[21] Employment Act (Cap 91) (Singapore) Measures) Notification 2020

(Singapore)

[22] Employment Rights Act 1996 (United Kingdom)

[23] East Asia Company (M) Bhd. v Valen Noel Yap (Award No. 130 of 1987) 
[24] Financial Times (2020). "Loss of working hours to equal 195m full-time jobs, UN agency warns". Financial Times. 7 April 2020. Retrieved 7 April 2020.https://www.cnbc.com/2020/03/16/china-economy-millionslose-their-jobs-as-unemployment-spikes.html

[25] Ganda Palm Services Sdn. Bhd., Teluk Intan v Ng Wah Chiew and 2 others (Award 40/1986 ILR)

[26] Goon Kwee Phoy v J \& P Coats (M) Bhd, [1981]2 MLJ 129

[27] H.A. Berney v Tronoh Mines Ltd. [1949] 15 MLJ 4

[28] Industrial Relations Act 1967 (Malaysia)

[29] Kaur, A. witherworldwide (5 August 2020). "Singapore: Were you fired or retrenched? Your employer may not tell you the difference" https://www.withersworldwide.com/en-gb/insight/were-you-fired-orretrenched-your-employer-may-not-tell-you-the-difference (28 October 2020).

[30] Lee, M.P., \& Detta, I.J. (2007). Business Law. Oxford University Press, Malaysia.

[31] Ministry of Manpower website. https://www.mom.gov.sg/employmentpractices/retrenchment/responsible-retrenchment

[32] Ministry of Manpower website. https://www.mom.gov.sg/employmentpractices/retrenchment/alternatives-to-retrenchment

[33] Ministry of Human Resources, Guidelines, Press Statement dated 5 February 2020.http://mpma.org.my/v4/wp-content/uploads/2020/02/Eng-Press-

Release-nCov-1.pdf (retrieved 31 October 2020).

[34] Ministry of Human Resources: Frequently Asked Questions (FAQ) on Movement Control Order, Ministry of Human Resources the COVID-19 outbreak

[35] Ministry of Human Resources: Frequently Asked Questions (FAQ) Vol. 3, Ministry of Human Resources of Malaysia, 2020. https://www.mohr.gov.my/images/FAQ_ON_MCO_MOHR_VOL3.pdf

[36] Ministry of Human Resources: Guidelines on Handling Issues Relating to Contagious Outbreaks Including Novel Coronavirus (2019-NCOV) (Malaysia) (Ministry of Human Resources Guidelines, Press Statement dated 5 February 2020)

[37] Movement Control Order (MCO) (Malaysia)

[38] Ministry of Manpower website, 2020 (Singapore)

[39] Malayan Tiles Manufacturers Ltd. v Non-Metallic Mineral Products manufacturing Employees Union (Award No. 11 of 1986)

[40] Milan Auto Sdn. Bhd. v Wong She Yen (1995) 3 MLJ 537

[41] Mohd Zakir Yusoff v. Telarix (M) Sdn Bhd (Award No. 349 of 2020)

[42] National Union of Cinema \& Amusement Workers v Shaw Computer \& Management Services Sdn. Bhd (Award No. 27 of 1978)

[43] Prevention and Control of Infectious Diseases Act 1988 (Act 342) (Malaysia) [44] Police Act 1967 (Malaysia) 
[45] Prevention and Control of Infectious Diseases (Measures within the Infected Local Areas) Regulations 2020 (Malaysia)

[46] Prevention, and Control of Infectious Diseases (Measures within Infected Local Areas) (No.2) Regulations 2020 (Malaysia)

[47] Pipraich Sugar Mills v Pipraich Sugar Mills Mazdoor Union AIR 1957 SC 95

[48] Radio \& General Trading Sdn Bhd and Pui Cheng Teck \& Anor (Award 243/1990)

[49] Stephen Bong v FOB (M) Sdn. Bhd. \& Anor (1999) 3 MLJ 411

[50] Temporary Measures for Reducing the Impact of Coronavirus Disease 2019 (Covid-19) Act 2020 (Malaysia)

[51] Tharmabalan Suppiah Velliah v. MSL Travel Sdn Bhd (Award No. 3081 of 2019)

[52] William Jacks \& Co. (M) Sdn. Bhd. v S. Balasingam (1987) CLJ 1

[53] World Bank. "The Global Economic Outlook During the COVID-19 Pandemic: A Changed World. (June 8, 2020).

https://www.worldbank.org/en/news/feature/2020/06/08/the-globaleconomic-outlook-during-the-covid-19-pandemic-a-changed-world (retrieved 25.10.2020)

[54] Yee Seng Plantations Sdn. Bhd. V Kerajaan negeri Terengganu \& Ors. [2000] 3 CLJ 666 